\title{
Preferences of Baby Products Manufactured using Modernised Machinaries in Rural Areas
}

\author{
R. Vasuki, M. Sankar, N. Mathan Kumar
}

\begin{abstract}
The marketer's responsibility is to position his product in such a manner so as to suit the tastes and preferences of the consumers. Consumer preference refers to the preference on the consumer for one brand of a product in relation to various other brands of the same products. Today more and more of consumers in India are becoming quality conscious. They insist on quality products and are prepared pay even more for it. An attempt is being made through this survey to find out the parents preference regarding the purchase and consumption of baby products.
\end{abstract}

Keywords - Consumer Preference, Market Responsibility

\section{INTRODUCTION}

In the present scenario, the "Baby products" has become the top priority for parents. It is the dire necessity for every father and mother to buy their baby products, so that their babies are provided with various products. As Indians are also going in for the nuclear family structure the grandmothers care has reduced considerably. Due to lack of time, they cannot give their baby home prepared cosmetics. Parents are in search of readymade product for their baby without much annoyance[1]-[4]. Hence, they purchase different types of baby products, which are available in the markets in order to fulfill their requirements. Leading companies have introduced varieties of baby products under its brand.

\section{OBJECTIVES}

To find out that what extent they have been satisfied after using the Johnson and Johnson' s baby products.

To determine whether the present users of Johnson baby products have the intension of switching over to other brands in future and what reason behind to switch over.

To provide suggestions on the basis of respondents opinion and views.

\section{A. Scope of the Study}

Revised Manuscript Received on December 16, 2019

R.Vasuki, Department of Science and Humanities, Bharath Institute of Higher Education and Research, Chennai , India. Email: vasukiteacher@gmail.com

M.Sankar, Department of Science and Humanities, Bharath Institute of Higher Education and Research, Chennai , India. Email: sankar06.phd@gmail.com

N. Mathankumar, Department of Science and Humanities, Bharath Institute of Higher Education and Research, Chennai, India. Email: ma.aswinkumar18@gmail.com
Baby cosmetics and toiletry products used by the children up to 3 years age are considered for the study.

1. The study attempts to high light the consumer preference in the purchase of Johnson and Johnson baby cosmetics and toiletry products and the other brand of baby cosmetics and toiletries also[5]-[8].

2. The study tries to attempt the satisfaction of the consumers towards the baby cosmetics and toiletry products.

3. The study tries to high light the motivating factor for the purchase of baby cosmetics and toiletry products.

\section{METHODOLOGY}

The study is based on facts and figures collected by conducting a survey. To carry out the study consumer were surveyed separately with the help of questionnaire[9]-[12].

\section{A. Sampling:}

From the population, a total of 150 respondents were selected at random basis. The researcher went directly to the houses of the respondent at random and the data collected from those who voluntarily came forward with sufficient information. out of 150, 130 respondents only gave proper details[13]-[15].

\section{B. Limitations of the Study}

1. This study mainly focuses on Johnson and Johnson baby cosmetics and toiletry products.

\section{RESULTS AND DISCUSSIONS}

$\checkmark$ The analysis carried out in the sample area revealed that most of the respondents are preferred the brand Johnson and Johnson baby products.

$\square$ Sex status analysis reveals that female are given more preference in the purchase of Johnson baby products.

$\square$ Young and middle age group respondents are given more preference in the purchase of Johnson baby cosmetics and toiletries.

$\square$ This study result out that government and private employee are purchasing the Johnson baby products than other occupational groups[16]-[19]

$\square$ Compared with illiterate, the literate respondents are given high preference for buying the Johnson baby products.

$\square$ High income group respondents showing their interest in purchasing the 


\section{Preferences of Baby Products Manufactured using Modernised Machinaries in Rural Areas}

Johnson baby products than low level income groups.

$\square$ Varieties of Johnson baby products are purchased by respondents those who are having one or two children.

$\square$ Media is the major factor influenced by the respondents in the purchase of Johnson baby products followed by Doctor advice.

$\square$ Majority of the respondents has seen the advertisement of Johnson and Johnson baby products only through television but advertisement alone does not influence the consumer preference towards a particular brand.

$\square$ Most of the respondent spend rupees hundred for purchase of Johnson baby products and they used the product above two years for their baby[20]-[22].

$\square$ Majority of the respondent satisfied with Johnson baby products. They satisfied with the following factors like product quality, price, quantity, availability, softness and reputation.

$\square$ The study result out that wipro baby products are the close competitor of Johnson and Johnson in the study area and the respondent next choice of buying preference is given to the same brand.

$\square$ Few respondents only change their current using brand. The main reason is they are dissatisfied with quality and price.

$\square$ Statistical analysis of correlation reveals that various factors influencing the sales of baby products are based on the consumer satisfaction.

$\square$ There is no significant difference between consumer preference for baby cosmetics and toiletry products and factor influencing the motivation, motivation alone does not influence the consumer preference towards a particular brand.

$\square$ There is no significant difference in the satisfaction level due to the influencing factors[23]-[24].

\section{CONCLUSION}

The Johnson baby soap is quickly dissolved in water, so company may concentrate on quantity.

Awareness programme should be made to insist the importance of using Johnson and Johnson baby products. Special campaigns must be done especially in slum areas.

To improve the advertisement Johnson Company may include the attractive slogan with their advertisement. This slogan should mainly reach the children.

It is opinioned that play things for babies can be offered to the consumers as free gift along with the baby products[25].

Different consumer looks different things, hence a variety of baby cosmetics and toiletry products are available in the market. Overall Johnson and Johnson baby products are the best baby cosmetics and toiletry for baby's skin. In the study area consumer accept the Johnson and Johnson baby product as their first preference. Even the Johnson and Johnson baby soap not only used for baby, it is also used by grownup people because of its softness and moisture.

\section{REFERENCES}

1) Vasanthi, S. \& Rabiyathul Basariya, S. 2019, "Influence of value analysis and cross training in industry", International Journal of Engineering and Advanced Technology, vol. 8, no. 6, pp. 1810-1811.

2) Velvizhi, R., Sri Gowtham, S. \& Jeya Priya, D. 2019, "Examination of early feedbacks for effective product retailing on E-commerce websites", International Journal of Engineering and Advanced Technology, vol. 8, no. 6 Special Issue 2, pp. 703-706.

3) Anuradha, C., Pothumani, S. \& Kavitha, R. 2019, "A novel method towards E-commerce", International Journal of Engineering and Advanced Technology, vol. 8, no. 6 Special Issue 2, pp. 535-538.

4) Thomas, J. \& Rabiyathul Basariya, S. 2019, "A study on the issues of financial ratio analysis", Indian Journal of Public Health Research and Development, vol. 10, no. 3, pp. 1079-1081.

5) Ramachandran, S. \& Rabiyathul Basariya, S. 2019, "Online marketing study on customer satisfaction and relationship", Indian Journal of Public Health Research and Development, vol. 10, no. 3, pp. 1072-1078.

6) Priya, R., Vinothini, G. \& Cor Jesu, C.D. 2019, "The mentor-protégé relationship for professional growth", Journal of Advanced Research in Dynamical and Control Systems, vol. 11, no. 9 Special Issue, pp. 1110-1119.

7) Jannifer Rani, N., Bina Pani, S. \& Nimisha, N.S. 2019, "A study on money back polices available in LIC", Journal of Advanced Research in Dynamical and Control Systems, vol. 11, no. 9 Special Issue, pp. 833-839.

8) Saillaja, V., Jhansi Rani, K. \& Catherine, R. 2019, "Global marketing management planning and organization", Journal of Advanced Research in Dynamical and Control Systems, vol. 11, no. 9 Special Issue, pp. 489-493.

9) Saillaja, V., Jhansi Rani, K. \& Catherine, R. 2019, "The new phase of marketing information system", Journal of Advanced Research in Dynamical and Control Systems, vol. 11, no. 9 Special Issue, pp. $482-488$.

10) Thoufiqulla \& Raju, D.V. 2019, "Perception of indian investor towards investment in mutual funds with special reference to mip funds", Journal of Advanced Research in Dynamical and Control Systems, vol. 11, no. 5, pp. 177-183.

11) Jasmine, K.R.M. \& Basariya, S.R. 2018, "A study on the customers benefits on mutual funds", International Journal of Civil Engineering and Technology, vol. 9 , no. 4, pp. 45-48.

12) Vasanthi, S. \& Basariya, S.R. 2019, "Pros and cons of on the job training versus off the job training", International Journal of Scientific and Technology Research, vol. 8, no. 10, pp. 671-674.

13) Pavithra, J. \& Ganesan, M. 2016, "A study on awareness and impact of micro-financial schemes", International Journal of Applied Business and Economic Research, vol. 14, no. 8, pp. 5449-5460.

14) Pavithra, J., Dilli Babu, P. \& Ambuli, T.V. 2014, "A study on budgetary control at Maruti Service Masters, Chennai", International Journal of Applied Business and Economic Research, vol. 12, no. 2, pp. 151-161.

15) Gunaraja, T.M. \& Venkatrama Raju, D. 2018, "Determining factors of organisational climate with reference to leadership styles", International Journal of Mechanical Engineering and Technology, vol. 9, no. 9, pp. 1327-1332.

16) Gunaraja, T.M. \& Venkatrama Raju, D. 2018, "The role of job satisfaction and training of employees in determining organisational climate of a selected industry", International Journal of Civil Engineering and Technology, vol. 9, no. 8, pp. 1266-1269.

17) Aarathy, T.S. \& Raju, D.V. 2018, "Performance appraisal and its effects on employees with respect to it sector in Chennai city", International Journal of Civil Engineering and Technology, vol. 9, no. 6, pp. 1535-1538.

18) Aarathy, T.S. \& Raju, D.V. 2018, "Employee perception towards performance appraisal system in IT sector", International Journal of Mechanical Engineering and Technology, vol. 9, no. 5, pp. 131-135.

19) Porselvi, W., Jublee, D. \& Sivanesan, G. 2018, "A study on factors influencing adoption of technology and innovation in banking industry, tamilnadu, India", International Journal of Mechanical Engineering and Technology, vol. 9, no. 5, pp. 789-800. 
20) Akessa, G.M. and Dhufera, A.G., 2015. Factors That Influences Students Academic Performance: A Case of Rift Valley University, Jimma, Ethiopia. Journal of Education and Practice, 6(22), pp.55-63.

21) Miller, G. and Shih, C.C., 1999. A faculty assessment of the academic rigor of on-and off-campus courses in agriculture. Journal of Agricultural Education, 40, pp.57-65.

22) Tsinidou, M., Gerogiannis, V. and Fitsilis, P., 2010. Evaluation of the factors that determine quality in higher education: an empirical study. Quality Assurance in education, 18(3), pp.227-244.

23) Farooq, M.S., Chaudhry, A.H., Shafiq, M. and Berhanu, G., 2011. Factors affecting students' quality of academic performance: a case of secondary school level. Journal of quality and technology management, 7(2), pp.1-14.

24) Fitsilis, P., Gerogiannis, V. and Anthopoulos, L., 2014. Ontologies for software project management: a review. Journal of Software Engineering and Applications, 7(13), p.1096.

25) Adams, J.D. and Jaffe, A.B., 1996. Bounding the effects of R\&D: an investigation using matched establishment-firm data(No. w5544). National bureau of economic research.

\section{AUTHORS PROFILE}

R.Vasuki Assistant Professor, Department of Science and Humanities Bharath Institute of Higher Education and Research, Chennai, India.

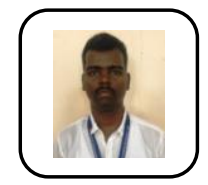

M.Sankar Assistant Professor, Department of Science and Humanities, Bharath Institute of Higher Education and Research, Chennai, India.

N. Mathankumar Assistant Professor, Department of Science and Humanities, Bharath Institute of Higher Education and Research, Chennai, India. 